At-Tarbawi: Jurnal Pendidikan, Sosial dan Kebudayaan

Volume 7 Nomor 1 Tahun 2020

doi: 10.32505/tarbawi.v7i1.2057

\title{
Relasi Kuasa Foulcout di Universitas Samudera Langsa
}

\author{
Masdalifah Sembiring \\ Dosen Fakultas Dakwah IAIN Langsa \\ masdalifah@iainlangsa.ac.id
}

\begin{abstract}
Despite applying Islamic sharia, the city of Langsa, through Universitas Samudera, was able to become a new magnet for non-Muslim students as an educational destination in Aceh. On the other hand, as a minority, their existence needs to be explored. This study aims to describe the forms of tolerance accepted by non-Muslim students, describe the impact of tolerance on their daily lives, and describe the power relations between lecturers and non-Muslim students. This research took place from May to October 2019 and involved five non-Muslim students, two religious lecturers, and a campus authority representative. This study uses a qualitative approach with ethnographic types and uses three methods of data collection, namely observation (fieldnotes), interviews (open-ended questions), and Focus Group Discussion (FGD) which are analyzed using reading, describing, and classifying techniques. The results of this study indicate that there are several forms of tolerance accepted by non-Muslim students, namely; the option to not take the semester exams and take grades from the church, the freedom to work on assignments according to their perspectives and beliefs, and given the freedom to participate in discussions. Apart from the power of lecturers to carry out Islamization, religious lecturers carry out their duties professionally. The effort of Islamization is carried out by providing a correct explanation of Islam accompanied by evidence of its truth, not in striking and coercive ways.
\end{abstract}

Keywords: Non-Muslim Students, Power Relations, Tolerance

\begin{abstract}
Abstrak
Meskipun menerapkan syari'at Islam, kota Langsa, melalui Universitas Samudera, mampu menjadi magnet baru bagi mahasiswa non muslim sebagai destinasi pendidikan di Aceh. Di sisi lain, sebagai minoritas, keberadaan mereka perlu untuk lebih didalami. Penelitian ini bertujuan untuk menggambarkan bentuk-bentuk toleransi yang diterima mahasiswa non muslim, menjabarkan dampak toleransi terhadap keseharian mereka, serta mendeskripsikan relasi kuasa antara para dosen dan mahasiswa non muslim. Penelitian ini berlangsung dari Mei hingga Oktober 2019 dan melibatkan lima orang mahasiswa non muslim, dua orang dosen mata kuliah keagamaan dan seorang perwakilan otoritas kampus. Penelitian ini menggunakan pendekatan kualitatif dengan jenis etnografi, dan menggunakan tiga metode pengumpulan data, yakni observasi (fieldnote), wawancara (open-ended questions) serta Focus Group Discussion (FGD) yang dianalisis menggunakan teknik reading, describing, and classifying. Hasil penelitian ini menunjukkan bahwa terdapat beberapa bentuk toleransi yang diterima mahasiswa non muslim yaitu; adanya opsi untuk tidak ikut ujian semester dan mengambil nilai dari gereja, adanya kebebasan untuk mengerjakan tugas sesuai perspektif dan keyakinannya, serta diberikan kebebasan dalam mengikuti diskusi. Terlepas dari kuasa dosen untuk melakukan Islamisasi, dosen keagamaan menjalankan tugasnya dengan professional. Usaha islamisasi dilakukan dengan memberikan penjelasan yang benar mengenai Islam disertai dengan bukti-bukti kebenarannya, bukan dengan cara-cara yang mencolok dan memaksa.
\end{abstract}

Kata Kunci: toleransi, mahasiswa non muslim, relasi kuasa 


\section{A. Pendahuluan}

Sejak abad ke 15 M, Aceh telah dikenal sebagai "Serambi Mekah". Salah satu alasan mengapa gelar yang sarat nuansa islami ini disematkan kepada Aceh karena Aceh merupakan pintu gerbang masuknya Islam di nusantara, melalui kawasan pantai timur, peureulak dan pasai. Selain itu, Aceh juga pernah menjadi pusat ilmu pengetahuan dengan hadirnya Jami'ah Baiturrahman yang menjadi tempat bagi para penuntut ilmu dari berbagai belahan dunia untuk belajar berbagai macam ilmu pengetahuan. Melalui pelabuhan Bandar Aceh Darussalam yang selalu ramai dan sibuk, Aceh pada masa lalu menjadi tempat persinggahan kapal-kapal yang membawa para calon jamaah haji sebelum mengarungi Samudera Hindia. Para calon Jamaah haji dapat menghabiskan waktu hingga enam bulan selama masa persinggahan tersebut. Karena menjadi tempat persinggahan sebelum ke Mekkah dan adanya persamaan kultur islami dengan Mekkah membuat Aceh mendapatkan gelar sebagai "Serambi Mekkah". Maka tidaklah mengherankan bila Aceh dikemudian hari menjadi satu-satunya provinsi di Indonesia yang menerapkan syari'at Islam sebagai salah satu landasan hukum serta menjadikan Al-Qur'an sebagai salah satu sumber hukum positif. Di Aceh, kehidupan bernafaskan islam mewarnai setiap lini sisi kehidupan dari penerapan hukum, pergaulan hingga pendidikan.

Salah satu kota yang menjadi tujuan pendidikan yang ada di Aceh adalah Langsa. Meski mayoritas penduduk kota Langsa berasal dari suku Aceh dan beragama Islam, namun hadirnya universitas-universitas negeri di kota Langsa turut menjadi magnet bagi datangnya pendatang dari berbagai suku dan agama yang menciptakan kemajemukan dalam masyarakat kota Langsa. Dan salah satu Universitas yang menjadi tujuan para pelajar non muslim dari luar Aceh adalah Universitas Samudera Langsa.

Ada beberapa alasan yang menyebabkan mahasiswa non muslim yang mayoritas berasal dari Sumatera Utara mengenyam pendidikan di Universitas Samudera Langsa. Pertama, status "Negeri" yang sudah di miliki oleh Universitas tersebut sejak tahun 2013. Tidak dapat dipungkiri bahwa masih banyak paradigma masyarakat yang memandang bahwa universitas 
negeri lebih baik daripada universitas swasta. Hal ini menyebabkan sejak tahun 2013 pula, banyak mahasiswa non muslim dari luar Aceh yang mulai mengenyam pendidikan di Universitas Samudera Langsa. Alasan lainnya adalah biaya kuliah dan biaya hidup di Aceh yang relatif lebih murah daripada di daerah lainnya. Biaya kuliah di Universitas Samudera dianggap masih relatif murah dan terjangkau daripada biaya kuliah di universitas yang terdapat di kota-kota lain, misalnya Medan, Riau atau Padang. Jarak kota Langsa yang relatif dekat dengan Sumatera Utara juga menjadi alasan yang menarik minat para pelajar non muslim yang umumnya berasal dari Sumatera Utara untuk melirik Universitas Samudera sebagai tempat untuk menimba ilmu.

Keberadaan mahasiswa non muslim di kota Langsa sendiri menimbulkan warna baru dalam kehidupan di kota Langsa, khususnya di gampong Meurandeh, yang merupakan gampong di mana Universitas Samudera Langsa berada sekaligus gampong yang menjadi tempat bagi para mahasiswa untuk tinggal. Warna inilah yang menyebabkan keberagaman di Meurandeh mulai terasa. Meski sebelumnya para mahasiswa memang berasal dari berbagai daerah dengan suku yang berbeda, namun perbedaan itu tidak terlalu terasa karena perbedaan penggunaan bahasa daerah dari berbagai mahasiswa yang berbeda suku dapat diatasi dengan mudah melalui penggunaan bahasa Indonesia. Namun, kemajemukan lebih terasa ketika ada mahasiswa yang berbeda agama. Dari segi berpakaian misalnya, sudah menjadi sebuah kewajiban dan kebiasaan bagi para mahasiswi untuk mengenakan jilbab di kampus dan di luar kampus, kecuali di dalam asrama/kos. Namun, hal ini tentu tidak berlaku bagi mahasiswi non muslim, sebab tidak ada kewajiban mengenakan jilbab dan menutup aurat dalam agama mereka. Jika kita melihat kehidupan perkuliahan di kota Medan, misalnya, keberadaan mahasiswi non muslim yang tidak berjilbab tentu menjadi pemandangan yang sangat biasa, namun, jika pemandangan ini hadir di kota langsa, tentu rasanya akan sangat berbeda sebab mata masyarakat sudah dibiasakan melihat pelajar yang selalu berjilbab, dari tingkat TK hingga perguruan tinggi. Di sinilah kemajemukan dan multikultur itu mulai terasa. 
Perbedaan suku dan agama tentu membuat mereka, sebagai minoritas dalam hal ini, harus menyesuaikan diri dengan peraturan dan budaya yang ada ditempat mereka menuntut ilmu, bagaimana bentuk-bentuk penyesuaian diri yang mereka lakukan, bagaimana cara mereka bernegosiasi dengan struktur social yang identik dengan syariat islam, dan bagaimana bentuk toleransi dalam pendidikan multikultural yang ada di Universitas Samudera.

Tidak hanya dalam kehidupan sehari-hari, kehidupan perkuliahan mahasiswa non muslim di Universitas Samudera juga sangat menarik untuk digali. Bagaimana bentuk-bentuk toleransi yang diberikan kepada mahasiswa non muslim. Toleransi adalah salah satu perekat heterogenitas yang ada di masyarakat. Fakta di lapangan yang menunjukkan penerapan toleransi di Universitas Samudera kepada para mahasiswa non muslim adalah adanya kebebasan untuk ikut atau tidak ikut dalam mata kuliah Agama Islam. Jika memilih tidak ikut, maka mereka diharuskan mengambil nilai dari gereja. Hal ini menunjukkan bahwa pilihan mahasiswa hanya pada dua hal, yakni "ikut/tidak ikut" dan tidak ada pilihan lainnya misalnya mendatangkan dosen khusus yang akan mengajarkan mereka mata kuliah agama sesuai dengan agama yang mereka anut. Sehingga mereka juga mendapatkan hak mereka seperti mahasiswa mayoritas lain untuk memperoleh pengajaran agama. Contoh ini menjadi pemicu munculnya argumen bahwa sebenarnya toleransi yang diterapkan di Universitas Samudera sudah dimodifikasi dan adanya negosiasi konsep toleransi dalam konteks Aceh.

Selama ini, konsep toleransi dimaknai secara tetap, yakni menghormati perbedaan dan seringkali mengabaikan konteks lokalitas dimana kata "toleransi" itu diterapkan. Melalui kajian ini, penulis ingin menggali dan menunjukkan bagaimana pemaknaan konsep toleransi itu sesungguhnya, bagaimana toleransi itu dinegosiasikan dan dipraktekkan dalam koteks lokalitas Aceh. Selain itu, hasil penelitian ini nantinya juga akan memberikan gambaran bagaimana saat ini otoritas Universitas Samudera Langsa dan dosen-dosen mata kuliah keagamaan melaksanakan tugas dan fungsinya baik dalam hal mengambil kebijakan atau mengajar dengan mempertimbangkan keberadaan mahasiswa non muslim di kampus tersebut. 


\section{B. Metode}

Penelitian ini dilakukan di Univeristas Samudera Langsa. Penelitian ini menggunakan pendekatan kualitatif dengan jenis etnografi. Miles dan Huberman (1994) menjelaskan bahwa penelitian kualitatif dilakukan melalui kontak yang intens dan / atau berkepanjangan dengan bidang atau situasi kehidupan. Situasi-situasi ini biasanya bersifat dangkal atau normal yang mencerminkan kehidupan sehari-hari individu, kelompok, masyarakat dan organisasi. Gay, Miles \& Airasian (2012) menekankan bahwa penelitian etnografi mengkaji tentang budaya dan perspektif seseorang terkait dengan sesuatu.

Teknik pengumpulan data yang digunakan dalam penelitian etnografi ini adalah observasi, wawancara serta Focus Group Discussion (FGD). Observasi untuk mengamati bentuk toleransiyang diambil oleh dosen Agama Islam di kelas yang terdapat mahasiswa non-muslim. Selain itu, observasi juga dilakukan untuk mengamati secara langsung aktivitas perkuliahan dan pergaulan mahasiswa non muslim di Universitas Samudera. Observasi yang dilakukan adalah Direct Observation yang melibatkan pengamatan subjek dalam situasi tertentu dan sering menggunakan teknologi seperti peralatan rekaman visual (Dawson, 2007). Data yang diperoleh dari observasi dinamakan fieldnotes. Fieldnotes adalah teks atau kata-kata yang direkam oleh peneliti selama observasi dalam penelitian kualitatif (Creswell, 2012). Selain menggunakan teknik observasi, peneliti juga menggunakan metode wawancara.

Wawancara digunakan untuk memperkuat keabsahan hasil data yang diperoleh melalui teknik pengamatan. Wawancara di sini dilakukan kepada berbagai pihak yang terkait untuk memperoleh data mengenai prosedur bagi mahasiswa nonmuslim dalam mengambil mata kuliah pendidikan agama, wawancara juga dilakukan dengan mahasiswa non muslim dan dosen mata kuliah keagamaan. Jenis wawancara yang digunakan dalam penelitian ini adalah semi-structured interview dimana peneliti ingin mengetahui informasi spesifik yang akan dibandingkan dan dikontraskan dengan informasi yang diperoleh pada wawancara lainnya sehingga pewawancara 
harus menanyakan pertanyaan yang sama kepada nara sumber (Dawson, 2007). Wawancara dilakukan dengan memberikan open-ended questions kepada sampel. Dalam penelitian kualitatif, open-ended questionsdigunakan sehingga para peserta dapatmenyuarakan pengalaman terbaik mereka tanpa dibatasi oleh perspektif peneliti atau masa lalutemuan penelitian. open-ended questionsjuga memungkinkan peserta untuk membuatopsi untuk merespons (Creswell, 2012).

Ketiga, untuk melengkapi data dari observasi dan wawancara, peneliti juga menggunakan teknik FGD dimana sejumlah orang diminta untuk duduk bersama dan membahas topik tertentu untuk mencapai tujuan penelitian. Focus Group ini difasilitasi oleh seorang moderator yang menanyakan beberapa pertanyaan, menggali secara detail, mengatur diskusi agar tidak menyimpang dan mencoba meyakinkan bahwa setiap orang berhak untuk memberikan masukan dan tidak ada orang yang mendominasi (Dawson, 2007).

\section{Hasil dan Pembahasan}

\section{1) Potret Mahasiswa non Muslim di Universitas Samudera Langsa}

Setidaknya, dalam satu kelas (unit) dari setiap fakultas di Universitas Samudera Langsa, terdapat lima hingga tujuh orang mahasiswa non muslim. Sementara itu, terdapat lima fakultas dengan 25 program studi yang ada di universitas yang berdiri sejak tahun 1985 ini, yaitu fakultas ekonomi, fakultas hukum, fakultas tekhnik, fakultas pertanian dan fakultas keguruan dan Ilmu pendidikanUmumnya, sebagian besar dari mahasiswa non muslim tersebut bertempat tinggal di rumah/kamar kos di gampong Meurandeh. Mereka tinggal secara berkelompok untuk memudahkan mereka beradaptasi dan berinteraksi dengan lingkungan tempat tinggal mereka yang baru.

Mahasiswa non muslim yang beragama Kristen, beribadah di Gereja Huria Kristen Batak Protestan (HKBP) yang terletak di Gampong Jawa, Langsa Kota, Kota Langsa, sedangkan untuk mereka yang menganut agama Budha (mayoritas berasal dari etnis Tionghoa), beribadah di Vihara Budha Langsa yang beralamat di Gampong Blang, Langsa Kota, Kota Langsa. 
Untuk berkumpul sesama mahasiswa non muslim, mereka tidak mempunyai organisasi tertentu. Mereka hanya sering dan rutin melakukan pertemuan untuk latihan koor atau menyanyi lagu-lagu religi. Dalam berkomunikasi, secara khusus, mahasiswa non muslim yang notabene memiliki latar belakang lingkungan, budaya dan keyakinan yang berbeda ini berkomunikasi dengan sesamanya menggunakan bahasa daerah mereka seperti bahasa batak atau bahasa mandarin, sedangkan secara umum, mereka menggunakan bahasa Indonesia dalam kesehariannya. Dalam hal berpakaian, tidak tampak adanya perbedaan antara mahasiswa non muslim laki-laki dengan mahasiswa muslim laki-laki pada umumnya, mereka tetap mengenakan pakaian sopan sesuai dengan tata tertib yang diterapkan dan kontrak belajar yang telah disepakati bersama antara dosen dan para mahasiswa. Namun, untuk mahasiswi non, perbedaan sangat mencolok terlihat dari cara mereka berbusana karena mereka tidak mengenakan jilbab dalam kesehariannya atau begitu juga dalam mengikuti perkuliahan. Namun, mereka tetap menggunakan busana yang sopan, memakai rok panjang dan baju berlengan panjang.

Untuk mahasiswa non muslim yang berasal dari suku batak, mereka berasal dari marga yang berbeda. Jika bertemu dengan mahasiswa lain atau pun senior yang bermarga atau pun bersuku sama, maka mereka saling menganggap sebagai saudara yang saling tolong menolong dan bekerja sama. Apalagi pada masa awal perkuliahan dimana mahasiswa baru masih diliputi rasa takut dan khawatir, bantuan dari senior sangatlah berharga.

\section{2) Bentuk-bentuk Toleransi Dosen agama Islam}

Keagamaan merupakan salah satu mata kuliah umum (MKU) yang diajarkan kepada mahasiswa yang menempuh pendidikan di Universitas Samudera Langsa. Mata kuliah ini berbobot 2 sks dengan total 16 kali pertemuan tatap muka. Karena merupakan mata kuliah umum, maka seluruh mahasiswa yang menempuh pendidikan di Universitas Samudera Langsa wajib mengambil mata kuliah ini, tidak terkecuali dengan mahasiswa non muslim. Pihak otoritas kampus sendiri tidak ada menyediakan fasilitas 
khusus bagi mahasiswa non muslim terkait dengan penyediaan mata kuliah pendidikan agama lain bagi mahasiswa non muslim.

Dalam mengajarkan mata kuliah keagamaan, dosen keagamaan mengajarkan agama Islam sebagai epistemologi, atau sebagai konsep, bukan sebagai sebuah keyakinan. Materi yang diajarkan antara lain ketauhidan, akidah, akhlak, perbedaan akhlak, etika dan moral, serta mengajarkan nilainilai universal yang tidak hanya diakui oleh Islam. Hal ini merupakan salah satu bentuk toleransi halus yang dosen coba untuk terapkan dalam mengajar dimana dosen yang bersangkutan mencoba untuk menggeneralkan nilai-nilai kebaikan yang terkandung dalam Islam kepada nilai-nilai yang berlaku universal, seperti menghormati orang tua dan guru.

Selain itu, dosen keagamaan juga melakukan upaya lain dalam melakukan proses pengajaran keagamaan, seperti mengupayakan pemberian tugas dengan menyesuaikan agama yang dianut oleh mahasiswanya misalnya dengan memberikan tugas menuliskan doa-doa tertentu bagi mahasiswa non muslim yang diambil dari kitab perjanjian lama.

Dalam pemberian nilai, dosen pun tidak melakukan diskriminasi berdasarkan agama mahasiswa. Terbukti bahwa rata-rata mahasiswa non muslim memperoleh nilai $\mathrm{B}+$ bahkan beberapa memperolah nilai $\mathrm{A}+$ dan secara keseluruhan semua mahasiswa non muslim yang mengambil mata kuliah keagamaan ini lulus dan tidak ada yang mengulang.

Untuk mendapatkan nilai dari mata kuliah pendidikan agama Islam ini pula, terdapat toleransi dari para dosen kepada mahasiswa non muslim, yakni mahasiswa dibebaskan untuk mengikuti ujian atau tidak. Jika mengikuti ujian akhir semester, maka nilai mata kuliah ini diberikan oleh dosen keagamaan yang mengajar di kelas tersebut. Namun, mahasiswa juga bisa meminta nilai dari gereja, dengan catatan tetap mengikuti perkuliahan seperti biasa. Jika nilai diperoleh dari gereja, tentu mahasiswa tersebut tidak harus mengikuti ujian semester. Untuk mendapatkan fasilitas seperti ini, maka mahasiswa dapat meminta langsung kepada dosen yang bersangkutan. 


\section{3) Toleransi dan keseharian mahasiswa non muslim}

Marcus et al, sebagaimana dikutip oleh Ansor et al (2010), mendefenisikan toleransi sebagai suatu sikap individu yang muncul ketika seseorang berhadapan dengan sejumlah perbedaan, dan bahkan pertentangan baik di tingkat sikap, pandangan, keyakinan, dan juga tindakan yang tumbuh di tengah masyarakat. Toleransi sendiri, bukanlah hal yang baru dalam Islam.

Secara umum, dalam konteks keseharian, toleransi dari lingkungan muslim kepada mahasiswa non muslim dapat ditandai dengan tiga bentuk, yaitu: saling menghormati, saling memberikan pertolongan dan memberikan kebebasan untuk beribadah menurut agama masing-masing. Bentuk-bentuk toleransi berikut dapat digambarkan melalui contoh-contoh di bawah ini.

Saat para mahasiswa menjalani kuliah di bulan suci Ramadhan, dimana mahasiswa muslim berpuasa, maka mahasiswa non muslim menghormati teman-temannya yang berpuasa. Mereka tidak makan dan minum dengan bebas di kampus bahkan di kos pun mereka sangat berhati-hati untuk makan dan minum.

Saat waktu azan sholat zuhur atau pun ashar dikumandangkan, maka para mahasiswa non muslim berhenti berbicara dan memilih untuk diam sejenak. Jika mereka saat itu sedang berdiskusi, maka mereka mempersilahkan mahasiswa muslim untuk sholat terlebih dahulu. Jika mereka sedang memainkan musik, maka mereka mematikan musiknya sejenak.

Bentuk toleransi lain yang terlihat antara mahasiswa non muslim dan mahasiswa muslim adalah saling menghormati dan menghargai cara berbusana masing-masing pemeluk agama. Bagi wanita muslimah, memakai jilbab adalah sebuah kewajiban sebagaimana yang tertera dalam surat An Nur ayat 19, tentang kewajiban bagi wanita musliman untuh berhijab dan juga dalam Qanun Aceh pasal 13 ayat 1 no. 11 tahun 2002. Para mahasiswa muslim, tidak mempermasalahkan pakaian mahasiswi non muslim yang tidak mengenakan jilbab, karena mereka memang tidak diperintahkan untuk berjilbab, asal mereka mengenakan pakaian yang sopan dan tertutup. Begitu 
juga dengan mahasiswa non muslim, mereka tidak memperolok pakaian wanita muslimah karena menyadari bahwa itu adalah bagian dari syari'at Islam. Mereka juga sangat menyadari bahwa mereka tinggal di Aceh yang memberlakukan syari'at Islam sehingga mereka harus menghormati peraturan yang ada.

Selain dalam bentuk saling menghargai, mahasiswa muslim dan non muslim memiliki pertemanan yang baik, tidak ada diskriminasi baik itu di dalam kelas atau pun dalam lingkup pertemanan, semua saling tolong menolong tanpa membedakan budaya dan keyakinan.

\section{4) Kuasa dosen dalam mengajarkan agama}

Kampus, sebagai salah satu institusi pendidikan, memegang peranan penting dalam proses penakhlukan seorang individu. Memasuki dunia kampus, berarti para mahasiswa harus tunduk dan patuh terhadap setiap peraturan dan regulasi yang ada di kampus tersebut.

Lebih jauh lagi, dosen, sebagai pengajar, memiliki peran yang sangat penting sebagai agen-agen dari jaringan kekuasaan yang telah terbentuk. Di sini, dosen memiliki kekuasaan penuh untuk memberikan pengajaran dan pendidikan kepada para mahasiswa. Kekuasaan ini juga, dimanfaatkan oleh sebagian dosen, untuk menggiring para mahasiswanya sesuai dengan keinginannya. Terkait dengan keberadaan mahasiswa non muslim yang turut mengambil mata kuliah umum Keagamaan, dosen memiliki kuasa penuh untuk menggiring mereka kepada Islam. Tentu, usaha-usaha itu tidak dilakukan secara jelas dan mencolok, apalagi melalui tindakan-tindakan pemaksaan, namun dilakukan secara halus dengan memanfaatnya kekuasaannya untuk mengatur dan mengelola kelas. Usaha-usaha dosen pendididikan agama Islam untuk menggiring para mahasiswa non muslim ke dalam Islam dapat dilihat dari beberapa contoh berikut ini:

1 Upaya untuk memberikan penjelasan yang benar terhadap Islam yang meliputi penjelasan mengenai ketauhidan, bahwa Allah itu satu disertai dengan dalil dan bukti tanpa menyinggung konsep trinitas nasrani. 
2 Memberikan penugasan kepada mahasiswa terkait materi pembelajaran yang membuat mahasiswa non muslim secara tidak langsung turut membaca materi-materi Islam secara lebih dalam seperti penugasan menghafal surah Al Ikhlas dan sebagainya.

3 Memberikan penjelasan mengenai Nabi Muhammad SAW, kemuliaannya, pengorbanannya, serta bukti-bukti kenabiannya.

4 Memberikan penjelasan bahwa umat Islam tidak membenci nabi Isa AS, melainkan mengimani beliau AS. Persepsi yang banyak dipercaya umat nasrani bahwa umat Islam membenci nabi Isa perlu diperjelas oleh dosen. Dalam hal ini dosen menerangkan kedudukan nabi Isa AS sangat mulia dalam Islam yaitu sebagai nabi/utusan Allah.

5 Memberikan penjelasan yang benar mengenai Al-Qur'an, kemuliaannya, isi kandungannya, serta kesucian dan keterjagaannya dari campur tangan manusia sejak diturunkan oleh Allah kepada Rasulullah SAW melalui perantara malaikat jibril hingga saat ini.

\section{Kesimpulan}

Berdasarkan hasil penelitian di atas, dapat ditarik beberapa hal yang menjadi kesimpulan dari penelitian ini, yakni:

1. Adaptasi dan keseharian; mahasiswa non muslim mampu beradaptasi dengan lingkungan tempat tinggal dan sistem perkuliahan yang diterapkan di universitas samudera Langsa. Mereka mampu menjalin pertemanan yang baik dan hubungan yang baik dengan lingkungan tempat mereka tinggal.

2. Kegiatan perkuliahan; dalam mengikuti perkuliahan, mahasiswa non muslim tidak mendapatkan perlakuan yang berbeda (diskriminasi) baik dari dosen atau pun dari teman-teman. Mereka dapat mengikuti perkuliahan dengan nyaman seperti mahasiswa muslim pada umumnya.

3. Toleransi dosen; terdapat beberapa bentuk toleransi yang dilakukan dosen keagamaan kepada mahasiswa non muslim, yaitu:

a. Mahasiswa non muslim diberi kebebasan untuk ikut/tidak ikut dalam ujian semester, dengan catatan mereka tetap harus bagus 
dari segi absensi dan mengikuti tugas serta ujian yang lain secara lengkap dan nilai ujian semester bisa digantikan dengan nilai dari gereja. Mahasiswa dapat memperoleh opsi ini jika mereka meminta langsung kepada dosen yang mengampu mata kuliah keagamaan di kelas mereka.

b. Mahasiswa non muslim diberikan kebebasan dalam mengerjakan tugas berdasarkan perspektifnya, sesuai dengan pandangan agama yang ia anut, dan tidak ada pembatasan harus mengerjakan sesuai dengan teori agama Islam seperti yang telah diajarkan oleh dosen.

c. Mahasiswa non muslim diberikan kebebasan untuk bertanya atau menjawab pertanyaan saat proses pembelajaran berlangsung dan mereka dapat terlibat secara aktif dalam diskusi dalam rangka mengikuti pembelajaran.

4. Kuasa dosen dan kecenderungan untuk Islamisasi; tidak ada upaya tersurat yang jelas dari dosen dalam menyatakan keinginannya untuk mengislamkan mahasiswa non muslim. Namun, terdapat upaya-upaya halus yang dilakukan oleh para dosen keagamaan untuk menggiring para mahasiswa non muslim menuju Islam. Upaya-upaya ini berupa penjelasan yang benar dan jelas tentang agama Islam disertai dengan bukti-bukti konkret.

5. Kebijakan dari Otoritas Kampus; tidak ada peraturan khusus bagi mahasiswa non muslim. Semua peraturan sama dan tidak ada pula diskriminasi dari pihak kampus. Semua mahasiswa baik muslim dan non muslim memiliki hak dan kewajiban yang sama sebagai mahasiswa di Unsam.

Berdasarkan kesimpulan di atas, peneliti mengajukan beberapa saran yang dapat dijadikan bahan pertimbangan, yakni:

1. Dalam mengajarkan materi agama Islam, para dosen agama Islam harus lebih memperluas perspektifnya, tidak hanya terbatas pada pandangan Islam saja, tetapi juga dari agama lain. Tujuan dari hal ini, bukan untuk menggiring dosen ke arah kristenisasi, namun agar dosen lebih mudah 
merangkul dan menggiring para mahasiswa non muslim dengan mencari celah dari perbedaan perspektif dari agama yang berbeda.

2. Dosen keagamaan juga harus menghindari upaya penekanan dan pemaksaan penggiringan kepada agama Islam kepada mahasiswa non muslim. Dan terus meningkatkan upaya dalam menerangkan Islam yang benar disertai dengan bukti-bukti yang konkret mengenai Islam sebagai agama yang jelas, damai, penuh kasih sayang dan menghindari konflik/permusuhan.

3. Agar materi perkuliahan dapat lebih mudah dicerna oleh mahasiswa non muslim, dosen seharusnya menjelaskan materi tersebut secara umum atau secara universal, tidak terlalu cenderung kepada agama Islam saja. Karena, saat penjelasan, dari sudut pandang dosen, yang notabene menganut agama Islam, materi tersebut mudah dipahami, namun, dari sudut pandang mahasiswa non muslim, ternyata materi tersebut sulit untuk dipahami. Oleh karena itu, alangkah baiknya jika dosen pendidikan agama, dalam menjelaskan materi agama Islam, jika menggunakan istilahistilah berbahasa arab, hendaklah menterjemahkan istilah tersebut dan dosen juga harus memperluas sudut pandangnya, tidak hanya dengan sudut pandang Islam, tapi juga sudut pandang non muslim, sehingga mahasiswa non muslim dapat lebih mudah mencerna materi keagamaan yang diajarkan oleh dosen.

\section{DAFTAR PUSTAKA}

Miles, M. B., \& Huberman, A. M. (1994) Qualitative Data Analysis: An Expanded Source Book Second Edition. SAGE Publications: California.

Gay, L. R., Mills, E. G \& Airasian, P. W. (2012) Educational Research: Competencies for Analysis and Applications (10th). Pearson: Boston.

Dawson, C. (2007) A Practical Guide to Research Methods: A User Friendly Manual for Mastering Researchs Techniques and Projects Third Edition. How To Content: Oxford.

Creswell, J. W. (2012) Educational Research: Planning, Conducting, And Evaluating Quantitative And Qualitative Research. Pearson Education : Boston. 
Anshor, M., Zubir, Muhammad, A. B. (2010). Hubungan Antara Religiusitas dan Sikap Terhadap Penerapan Syariat Islam di Kota Langsa - Propinsi Aceh. Langsa: STAIN Zawiyah Cot Kala Langsa. 